\title{
Analysis of the regulation of fatty acid binding protein 7 expression in human renal carcinoma cell lines
}

\author{
Naohisa Takaoka', Tatsuya Takayama*, Takumi Teratani², Takayuki Sugiyama', Soichi Mugiya and \\ Seiichiro Ozono ${ }^{1}$
}

\begin{abstract}
Background: Improving the treatment of renal cell carcinoma (RCC) will depend on the development of better biomarkers for predicting disease progression and aiding the design of appropriate therapies. One such marker may be fatty acid binding protein 7 (FABP7), also known as B-FABP and BLBP, which is expressed normally in radial glial cells of the developing central nervous system and cells of the mammary gland. Melanomas, glioblastomas, and several types of carcinomas, including RCC, overexpress FABP7. The abundant expression of FABP7 in primary RCCs compared to certain RCC-derived cell lines may allow the definition of the molecular components of FABP7's regulatory system.
\end{abstract}

Results: We determined FABP7 mRNA levels in six RCC cell lines. Two were highly expressed, whereas the other and the embryonic kidney cell line (HEK293) were weakly expressed FABP7 transcripts. Western blot analysis of the cell lines detected strong FABP7 expression only in one RCC cell line. Promoter activity in the RCC cell lines was 3to 21-fold higher than that of HEK293. Deletion analysis demonstrated that three FABP7 promoter regions contributed to upregulated expression in RCC cell lines, but not in the HEK293 cell. Competition analysis of gel shifts indicated that OCT1, OCT6, and nuclear factor I (NFI) bound to the FABP7 promoter region. Supershift experiments indicated that BRN2 (POU3F2) and NFI bound to the FABP7 promoter region as well. There was an inverse correlation between FABP7 promoter activity and BRN2 mRNA expression. The FABP7-positive cell line's NFIDNA complex migrated faster than in other cell lines. Levels of NFIA mRNA were higher in the HEK293 cell line than in any of the six RCC cell lines. In contrast, NFIC mRNA expression was lower in the HEK293 cell line than in the six RCC cell lines.

Conclusions: Three putative FABP7 promoter regions drive reporter gene expression in RCC cell lines, but not in the HEK293 cell line. BRN2 and NFI may be key factors regulating the expression of FABP7 in certain RCC-derived cell lines.

\section{Background}

Among primary renal tumors the most common is renal cell carcinoma (RCC). Although earlier detection of RCC has positively influenced patient outcomes [1], predicting both disease progression and patient response to treatment is difficult, due in part to the lack of suitable molecular markers [2].

\footnotetext{
* Correspondence: ttakayam@hama-med.ac.jp

'Department of Urology, Hamamatsu University School of Medicine,

Hamamatsu, Shizuoka, Japan

Full list of author information is available at the end of the article
}

FABP7 belongs to a mammalian family of at least nine proteins that are specifically expressed in diverse tissues such as liver, intestine, heart, adipose tissue, epidermis, brain, peripheral nervous system, and testis [3]. Several members of the FABP family play important roles in regulating metabolism and have been implicated in contributing to the development of insulin resistance and the metabolic syndrome [4].

Studies on human tumors and tumor-derived cell lines have indicated both FABP7's potential involvement in tumorigenesis and usefulness as a tumor marker [5-16]. Expression analyses have demonstrated FABP7 
transcripts in tumors or urine of patients with RCC [5-8], as well as in tissues in those with glioblastoma [9] and melanoma [10,11]. FABP7 mRNA [5-8] and FABP7 protein $[5,6,8]$ are overexpressed in RCC. FABP7 overexpression correlates with shorter survival in patients with glioblastoma $[9,12,13]$ and melanoma $[10,14,11]$, but better outcomes in those with breast cancer [15]. FABP7's role as a tumor suppressor is suggested by the finding that its enforced overexpression inhibits proliferation of a breast cancer cell line [16]. These findings clearly indicate the importance of determining how FABP7 expression is regulated. NFI and Pbx/POU binding sites have been found to be present in the FABP7 promoter in humans [17-19]. In glioma cell lines, NFI dephosphorylation is correlated with FABP7 expression [17]. In fact, all four members of the NFI family of transcription factors play key roles in the regulation of $F A B P 7$ in glioma cell lines [18]. Sánchez-Font et al. have suggested that $F A B P 7$ overexpression, controlled by the transcription factor PKNOX1, contributes to Down Syndrome-associated neurological disorders [19].

Here, we investigated the molecular mechanisms controlling FABP7 expression in human RCC cell lines.

\section{Results}

\section{FABP7 expression by RCC cell lines}

We previously analyzed $F A B P 7$ mRNA expression in primary surgically resected RCCs and were able to detect FABP7 mRNA in the tumor, but not in normal tissue [6,7]. Figure $1 \mathrm{~A}$ and Additional file 1 show the results of real-time polymerase chain reaction (quantitative PCR; Q-PCR) analysis of six RCC cell lines for $F A B P 7$ transcripts. Two RCC cell lines (OS-RC-2 and TUHR14TKB) exhibited strong FABP7 expression, in contrast to four other RCC cell lines (769-P, 786-O, ACHN and Caki-1) and a human embryonic kidney cell line (HEK293). These results differ from our analysis of primary RCCs, which expressed FABP7 at high frequency (80\%) [7]. We also performed Western blot analysis for FABP7 expression in these same cell lines (Figure 1C, Additional file 2). A band corresponding to the major $15 \mathrm{kDa}$ isoform [12] was detected at the highest level in TUHR14TKB, whereas it was not detectably expressed by HEK293 and other RCC cell lines (Figure $1 C)$. The $19 \mathrm{kDa}$ FABP7 isoform potentially generated by alternative splicing (AK289836, AL512688; [20]) was not detected (Additional file 2).

\section{Cis-acting elements in the $F A B P 7$ promoter}

We prepared $F A B P 7$-luciferase constructs to determine the location of 5'-flanking $F A B P 7$ regulatory elements active in RCC cell lines. All promoter constructs extend from 89 base pairs (bp) downstream from the transcription start site to various upstream sites as described in
Figure 2. The promoter activity of the -1122 to +89 FABP7 fragment in RCC cell lines was 3 - to 21 -fold higher than that of HEK293 (Figure 1B andAdditional file 1). FABP7 promoter activity did not correlate with mRNA and protein expression. The promoter deletion analyses shown in Figure $3 \mathrm{~A}$ and Additional file 1 demonstrates the presence of a strongly positive cis-regulatory element between nucleotide positions -192 and -36. Interestingly, a relatively small increase ( 3 fold) was exhibited by the HEK293 transfectant (Figure 3A, Additional file 1). In order to more precisely localize the promoter site, we conducted detailed deletion analysis between positions -192 and -36, summarized in Figure $3 \mathrm{~B}$ and Additional file 1 . Interestingly, the positive regulatory region between -83 and -36 was more active in RCC cell lines than in HEK293, so we conducted more detail deletion analysis of the region between positions -83 and -36 (Figure 3C, Additional file 1). Compared to the promoter activity of $-36+89$ construct transfectant, a 2 to 3 fold increase in luciferase activity was observed with the $-72+89$ transfectant. In contrast, no increase was observed in HEK293 (Figure 3C, Additional file 1). The results demonstrate the presence of multiple positive cis-regulatory elements within the region bounded by nucleotides -72 to -36 .

\section{Transcription factor binding to the $F A B P 7$ promoter}

We analyzed the $F A B P 7$ promoter region in silico using the TFBIND [21] and TESS [22] programs and by visual inspection with the TESS [22] to identify transcription factors binding to the FABP7 promoter of -72 to -36 . OCT1, OCT6, BRN2, C/EBP- $\alpha$, NFI, C/EBP- $\beta$, YY1, and SP1 binding sites were found across the promoter region (-73 to $-28 \mathrm{bp}$ ) (Figure 4 ).

We next performed mobility shift assays to determine the factors binding to the three RCC-specific up-regulated regions of the FABP7 promoter. Three doublestranded oligonucleotides named upstream probe (UP), middle probe (MP), and downstream probe (DP) (Table 1 and Figure 4), which represent the active regions within the -73 to -28 sequence $(-72$ to $-61 \mathrm{bp},-61$ to $-48 \mathrm{bp}$, and -48 to $-36 \mathrm{bp}$ ) and used the double stranded oligonucleotides as gel shift probes.

The UP detected a major band migrating at the same position in all nuclear extracts, and an additional HEK293-specific species (Figure 5A). A common shifted band (black arrows) was observed that could be competed by the addition of excess amounts of cold doublestranded OCT1 or OCT6 oligonucleotides (Figure 5B). However, the addition of anti-OCT1 or anti-OCT6 antibody to the binding reaction did not change the band shift pattern (Figure $5 \mathrm{C}$ ). Interestingly, the addition of excess amounts of C/EBP- $\alpha$, OCT1, or OCT 6 probes shifted the bands up (yellow arrows) (Figure 5B). We 


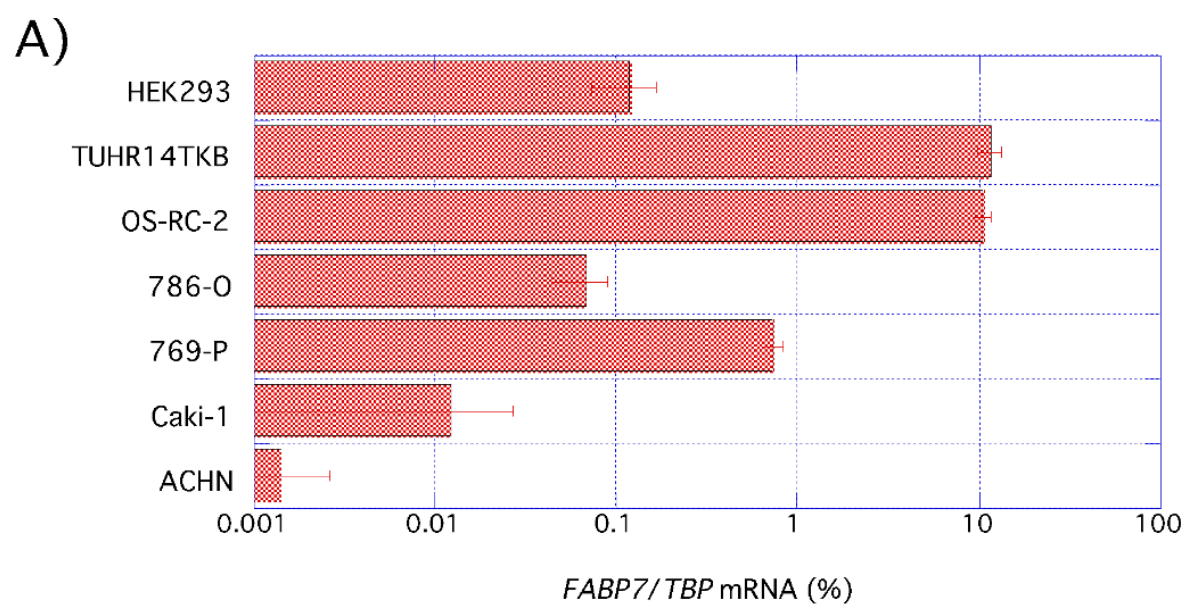

B)

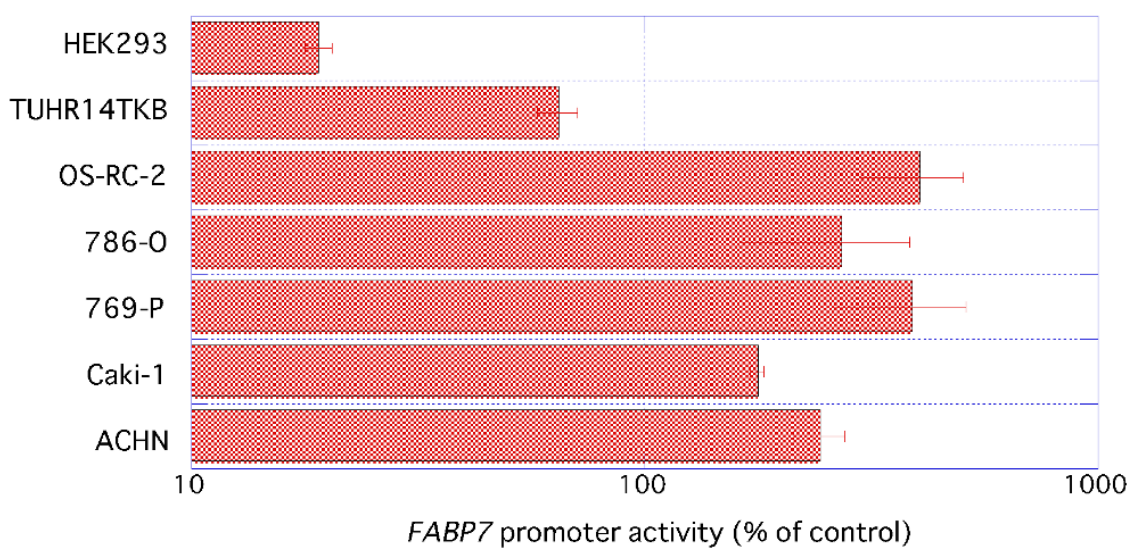

C)

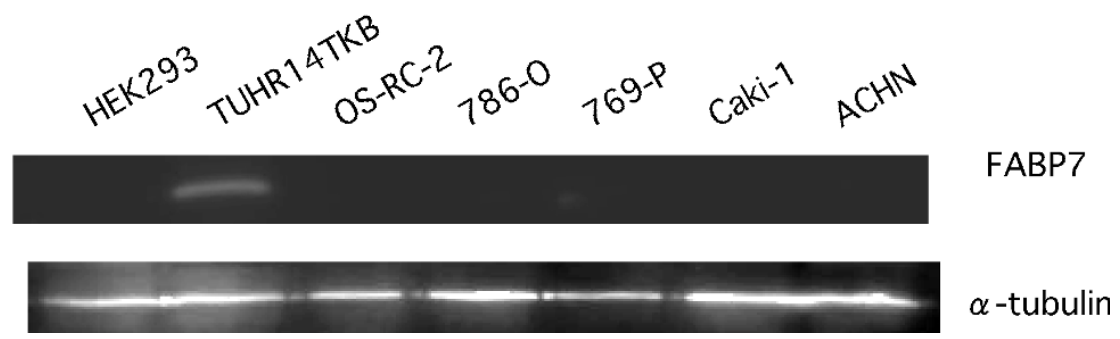

Figure 1 FABP7 expression in RCC cell lines. A) Q-PCR analysis was performed using total RNA extracted from a human embryonic kidney (HEK293) and RCC (TUHR14TKB, OS-RC-2, 786-O, 769-P, Caki-1, and ACHN) cell lines. FABP7 expression was determined with Q-PCR by the primers listed in Table 2. B) HEK293 and RCC (TUHR14TKB, OS-RC-2, 786-O, 769-P, Caki-1, and ACHN) cells were cotransfected with the -1122+89 pGL4-FABP7 promoter construct, and cultured for one day. Extracts prepared from transfected cells were assayed for luciferase activity. FABP7 promoter activities were normalized to the control's Renilla luciferase activity. The results shown are an average of four independent experiments with standard deviations indicated by the error bars. C) Western blot analysis was performed using cytoplasmic extracts from HEK293 and RCC (TUHR14TKB, OS-RC-2, 786-O, 769-P, Caki-1, and ACHN) cell lines.

speculated that some protein-DNA binding might prevent weak protein-DNA binding shifted up by addition of the cold probe.

To investigate whether the HEK293-specific band (yellow arrow, Figure 5A) was BRN2-dependent, addition of BRN2 antibody to the reactions resulted in a supershift (indicated by the * in Figure 5C). We could not make clear the reason why BRN2 oligonucleotide did not change the band shift pattern. It might be the effect of band shift that shifted up the addition of excess amounts of probe (yellow arrows, Figure 5B). To demonstrate the specificity of the BRN2 antibody used 


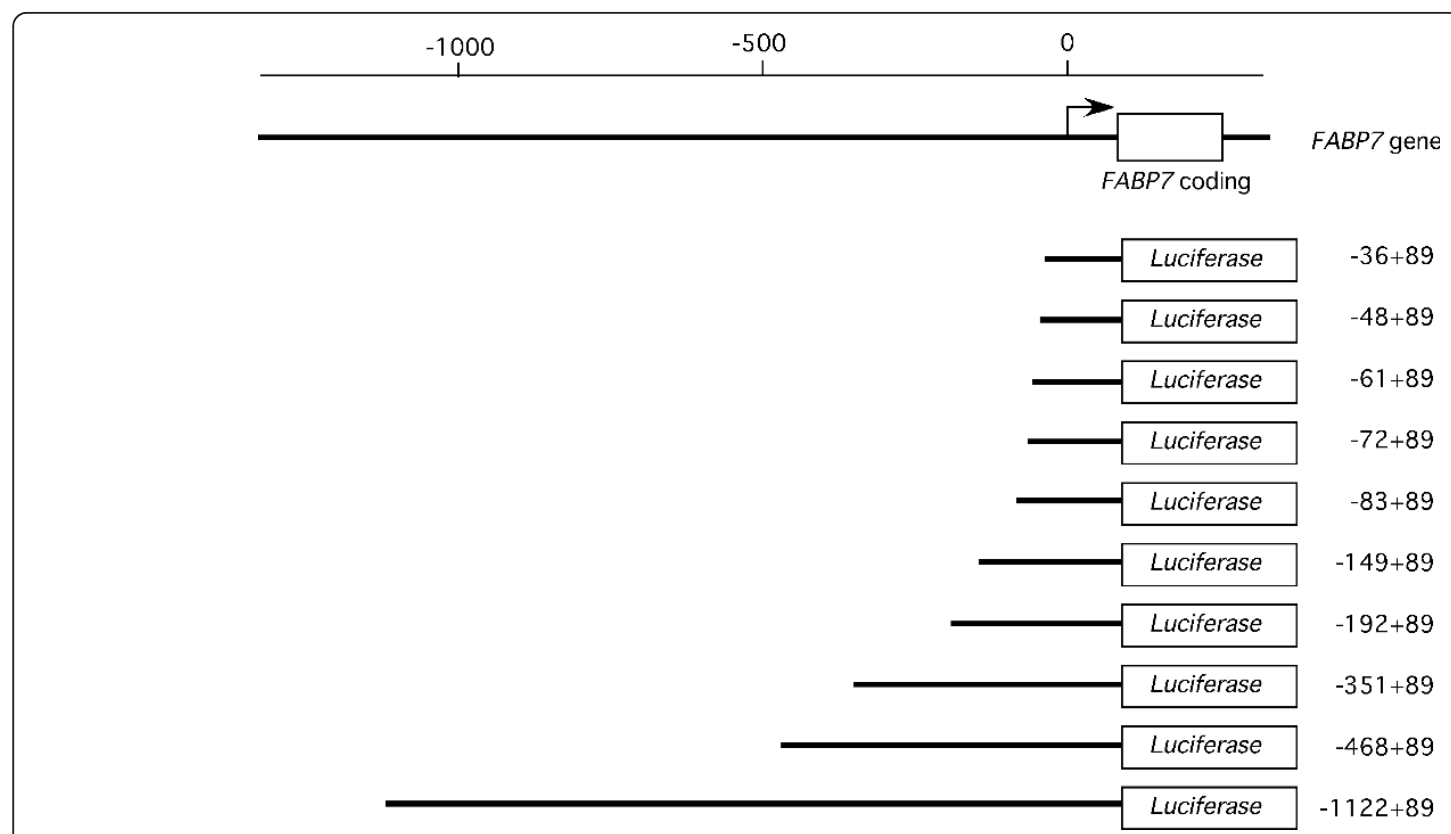

Figure 2 The pGL4-FABP7 promoter constructs. Schematic diagram of the FABP7 promoter showing the transcription start site (arrow, [17]) and coding regions (filled box). The pGL4-FABP7 promoter constructs extended from a common site $+89 \mathrm{bp}$ from the transcription start site to sites upstream $(-36,-48,-61,-72,-83,-149,-192,-351,-468$ and -1122 bp) were prepared by ligating PCR products to pGL4.17.

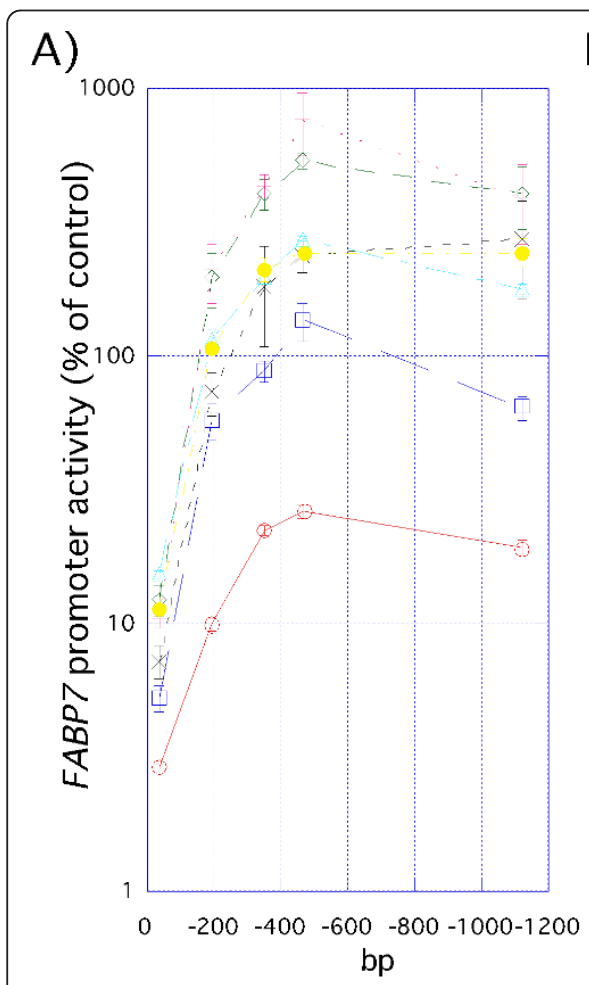

HEK293
B)

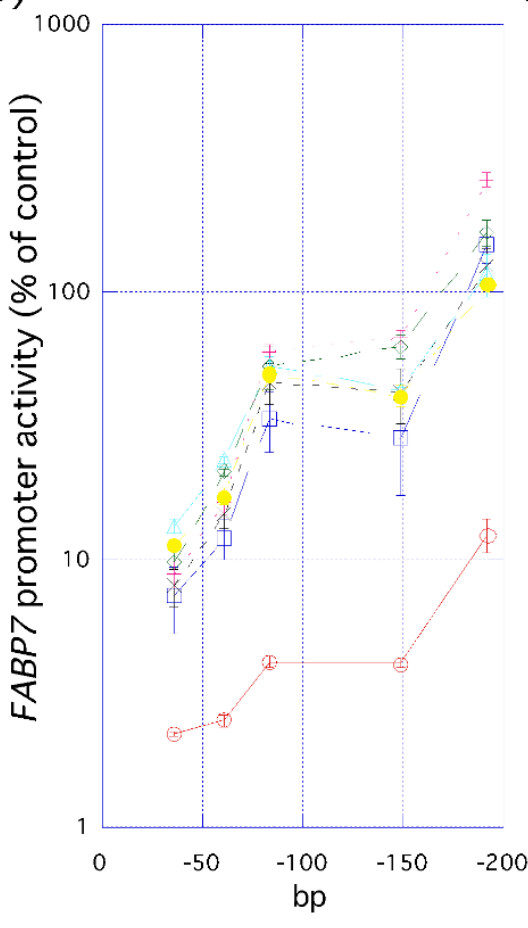

C)

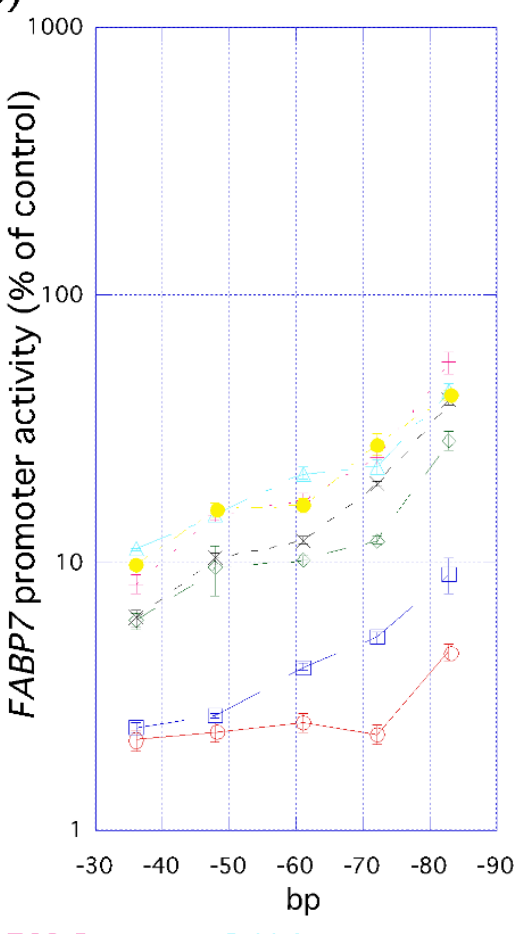

Figure 3 FABP7 promoter deletion analysis. HEK293 and RCC (TUHR14TKB, 786-O, 769-P, OS-RC-2, Caki-1, and ACHN) cells were cotransfected with the pGL4-FABP7 promoter constructs described above and the pGL4.74 plasmid control, and cultured for one day. Extracts prepared from transfected cells were assayed for luciferase activity. FABP7 promoter activities were normalized to the control's Renilla luciferase activity. The results shown are an average of at least three independent experiments with standard deviations indicated by the error bars. A: Deletion analysis of the FABP7 promoter region. B, and C: analyses of additional deletions. 


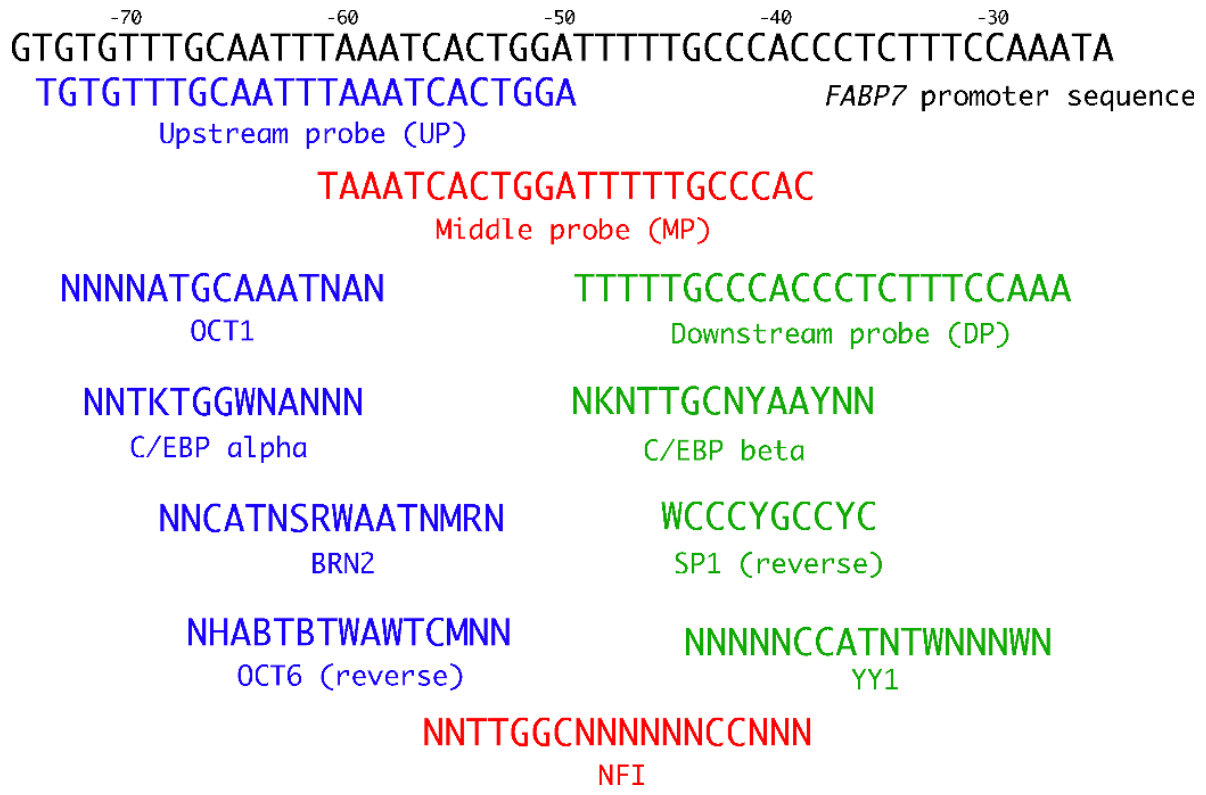

Figure 4 FABP7 promoter cis-regulatory region identified by promoter deletion analysis. Numbering starts from the $F A B P 7$ transcription start site [17]. Oligonucleotides designated upstream (UP), middle (MP) and downstream (DP) probes are shown along with putative consensus binding sites for OCT1, C/EBP- $\alpha$, BRN2, OCT6, NFI, C/EBP- $\beta$, SP1, and YY1.

for these studies, we showed that the HEK293-specific band detected by Western blot analysis was weaker when BRN2 was depleted using small interfering RNA (siRNA) (Figure 6B). Furthermore, the HEK293-specific

\section{Table 1 Gel shift probes}

\begin{tabular}{|c|c|}
\hline Name & Sequence Sense or Antisense \\
\hline \multirow[t]{2}{*}{ Upstream probe } & TGTGTTTGCAATTTAAATCACTGGA \\
\hline & TCCAGTGATTTAAATTGCAAACACA \\
\hline \multirow[t]{2}{*}{ Middle probe } & TAAATCACTGGATTITTGCCCAC \\
\hline & GTGGGCAAAAATCCAGTGATTTA \\
\hline \multirow[t]{2}{*}{ Downstream probe } & TTTTGCCCACCCTCTTTCCAAA \\
\hline & TाTGGAAAGAGGGTGGGCAAAAA \\
\hline \multirow[t]{2}{*}{ C/EBP alpha } & TCTITGGAAAGGT \\
\hline & ACCTTCCAAAGA \\
\hline \multirow[t]{2}{*}{ OCT1 } & GTAAATGCAAATCAG \\
\hline & CTGATTTGCATTTAC \\
\hline \multirow[t]{2}{*}{ BRN2 } & GCCATTCGAAATGAGC \\
\hline & GCTCATTTCGAATGGC \\
\hline \multirow[t]{2}{*}{ OCT6 } & GAGGAATTAGACTGC \\
\hline & GCAGTCTAATTCCTC \\
\hline \multirow[t]{2}{*}{ NFI } & TCTTGGCAAGAAGCCAAG \\
\hline & CTTGGCTTCTTGCCAAGA \\
\hline \multirow[t]{2}{*}{ C/EBP beta } & AGCTTGCACAACTC \\
\hline & GAGTTGTGCAAGCT \\
\hline \multirow[t]{2}{*}{ YY1 } & GATAACCATITITGAAC \\
\hline & GTTCAAAAATGGTTATC \\
\hline \multirow[t]{2}{*}{ SP1 } & TGAGGCAGGGT \\
\hline & ACCCTGCCTCA \\
\hline
\end{tabular}

shifted band (yellow arrow, Figure 6C) was not apparent in BRN2 specific siRNA transfectant.

RCC cell lines expressed more than five times less BRN2 mRNA than HEK293s (Figure 7A andAdditional file 1) and BRN2 protein expression was higher in HEK293 than RCC cell lines (Figure 7B). There was an inverse correlation between $F A B P 7$ promoter activity (Figure 1B) and BRN2 mRNA expression (Figure 7A), in HEK293s and RCCs (correlation coefficient, $r=-0.73$, Additional file 1). This result indicates that BRN2 represses the $F A B P 7$ promoter.

Bisgrove et al. reported that NFI binds to the region bounded by nucleotides -54 to $-40 \mathrm{bp}$ of the FABP7 promoter [17], corresponding to the middle probe (MP), and point mutations in this region attenuate $F A B P 7$ promoter activity. When we performed gel shift analysis with MP, a major DNA-protein complex was observed in all seven cell lines (Figure 8A). The band marked by the blue arrow was competed by an NFI oligonucleotide in HEK293 cell line and TUHR14TKB cell line (Figure $8 \mathrm{~B})$. Addition of the anti-NFI antibody to the binding reaction supershifted the NFI-DNA complex in HEK293 and TUHR14TKB cell lines (indicated by the *in Figure 8C). TUHR14TKB's NFI-DNA complexes migrated differently than those of the other cell lines (Figure 8A). FABP7 expression (Figure 1C) correlated with FABP7 promoter activation ( -61 to $-48 \mathrm{bp}$ ) (Figure $3 \mathrm{C}$ and Additional file 1) and NFI gel shift patterns (Figure 8A).

The NFI transcription factor family includes four genes: NFIA, NFIB, NFIC and NFIX [23]. In an effort to 

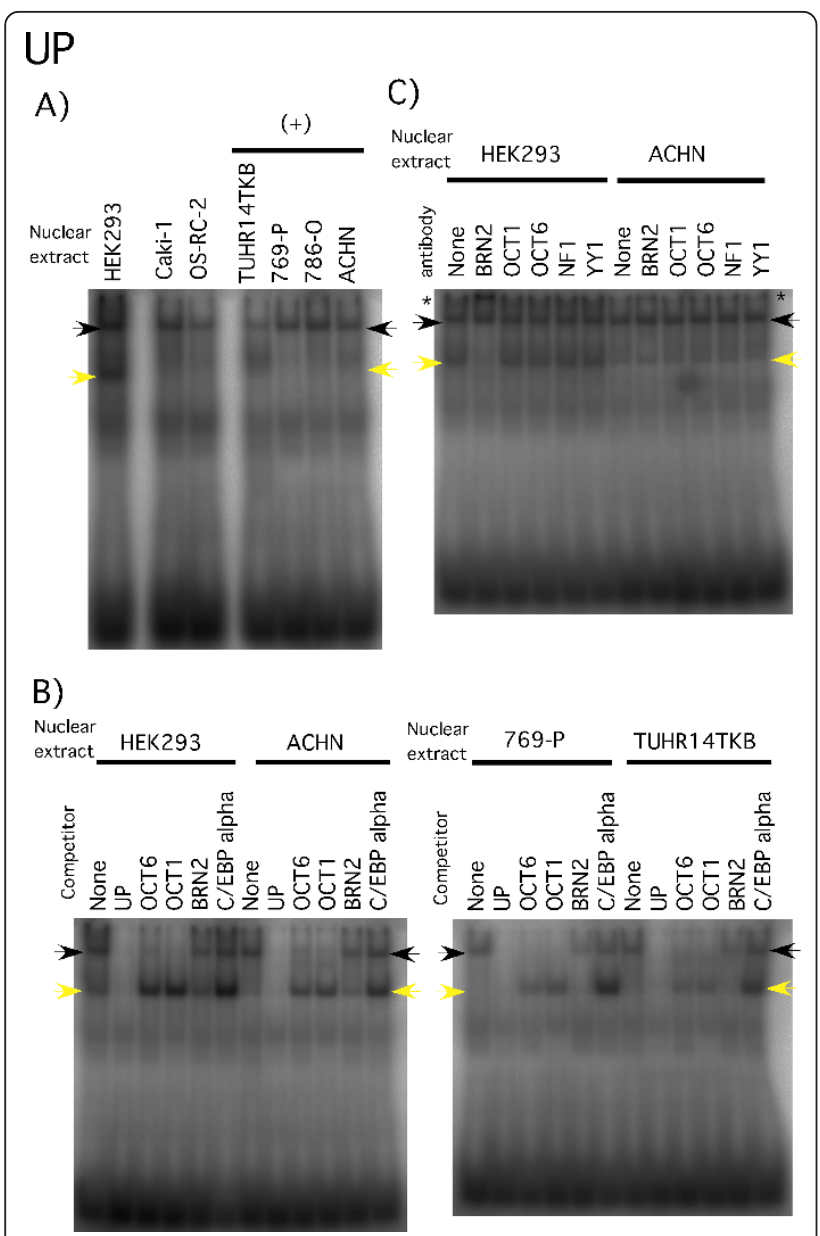

Figure 5 Gel shift analysis with the UP probe. A) ${ }^{32}$-labeled UP (Table 1 and Figure 4) were added to HEK293 or RCC (Caki-1, OSRC-2, TUHR14TKB, 769-P, 786-O, and ACHN) nuclear extracts. In (+) cell line, luciferase activity of $-72+89$ vector transfectant was increased above $30 \%$ than that of $-61+89$ vector transfectant. Arrowheads indicate significant band shifts. B) Competition analysis. Table 1 describes the oligonucleotide sequences. A 100-fold excess of unlabeled oligonucleotide indicated in the figure was added to each reaction. C) Five micrograms of HEK293 or ACHN nuclear extracts were incubated with $2 \mu \mathrm{g}$ of antibody (see figure) on ice for 30 min prior to addition of the ${ }^{32}$ P-labeled oligonucleotide probes. The ${ }^{* \prime \prime}$ shows anti-BRN2 induced supershifts.

determine which $N F I$ family member or members might interact with the $F A B P 7$ promoter, we determined NFI family members' mRNA levels. NFIA and NFIC mRNA levels were, respectively, weaker and stronger in all six RCC cell lines than in HEK293 (Figure 7C). NFIB and NFIX mRNA levels were approximately the same in all seven cell lines (Figure 7C).

When DP was subjected to gel shift analysis, only one weak band was observed (Additional file 3A). This band did not compete with any of the oligonucleotides representing transcription factor binding sites, whereas addition of excess amounts of C/EBP- $\beta$ probe shifted the band up (Additional file 3B). In contrast, addition of YY1 antibody did not alter this band's mobility (Additional file 3C).

\section{Discussion}

Approximately $70 \%$ of RCC patients survive for 5 years. However, the presence of distant metastases dramatically lowers survival, indicating the importance of developing better biomarkers for predicting disease course and designing suitable therapies. Overexpression of $F A B P 7$ in tumor tissue and urine of patients with RCC, [5-8] led us to consider FABP7 as such a biomarker and to elucidate the regulation of its expression.

As an initial approach, we chose to study FABP7 expression in cell lines derived from human RCCs and embryonic kidney. Our finding of strong FABP7 mRNA expression by two of six RCC cell lines (Figure 1A) varies from our previous finding of $80 \%(n=54)$ overexpression by carcinoma compared to corresponding expression in normal tissues [7]. Seliger et al. conducted studies related to ours that demonstrated FABP7 transcripts in 18 of 27 clear cell-type RCC lesions but only 4 of 19 RCC cell lines [5]. These observations may reflect the fact that higher grade (G3 + G4) versus lower grade $(\mathrm{G} 1+\mathrm{G} 2)$ tumors expressed significantly lower FABP7 mRNA levels [8]. Furthermore, ACHN and Caki-1 cell line, which expressed $F A B P 7$ mRNA weaker than other (Figure 1A), isolated from malignant pleural effusion and cutaneous metastasis each $[24,25]$. And FABP7 mRNA expression of 786-O cell lines was weaker than that of 769-P cell lines (Figure 1A). That $\mathrm{RCC}$ cases with poorer prognoses tend to express lower FABP7 levels, is consistent with the fact that the 786-O cell line was isolated from a patient with a prognosis less favorable than the patient from which the 769-P cell line was derived [26]. Several parallel studies have been conducted using other tumors. For example, primary versus metastatic melanomas express higher FABP7 mRNA levels [11]. FABP7-positive, compared to $F A B P 7$-negative, breast cancer patients experienced significantly longer disease-free survival and breast cancer specific survival [15]. The role of FABP7 as a tumor suppressor in human mammary cells is suggested by the demonstration that its enforced overexpression inhibits breast cancer cell proliferation [16]. In contrast, a recent study showed that down-regulating FABP7 using RNA interference techniques inhibited cell proliferation and migration but did not affect the invasive properties of the Caki-2 RCC cell line [27]. This suggests that the role of FABP7 in tumorigenesis depends on cell-specific regulatory factors.

We noted a discrepancy between endogenous FABP7 mRNA expression and the activity of the FABP7 promoter in cell lines derived from RCCs (786-O, ACHN, 
A)

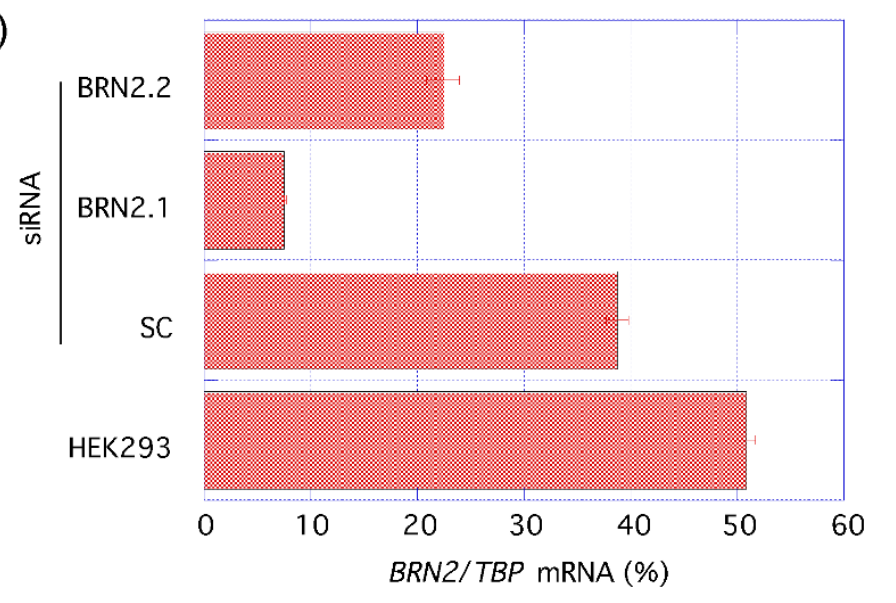

B)

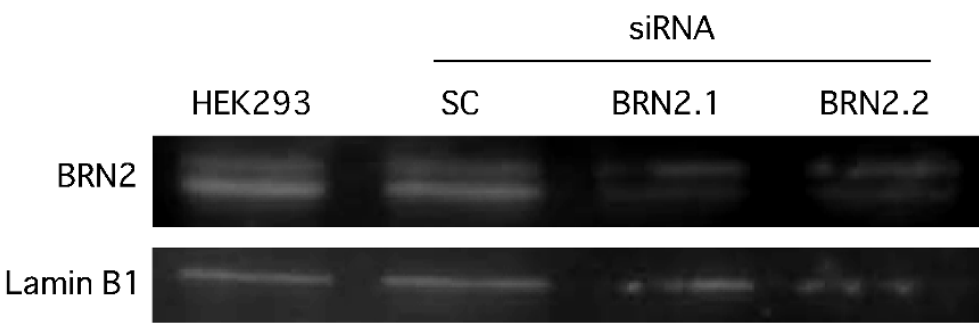

C)

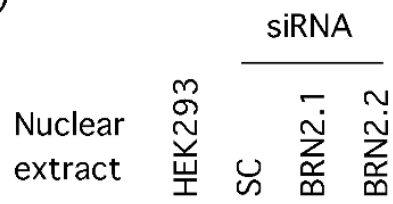

Figure 6 BRN2 knockdown. HEK293 cells were transfected with scrambled (SC) or BRN2 (BRN2.1 or BRN2.2) siRNAs. A) Q-PCR analysis for BRN2 to confirm efficient BRN2 knockdown. BRN2 was amplified using the primers shown in Table 2. B) Western blot analysis of BRN2 expression to confirm efficient BRN2 knockdown. C) Gel shift analysis for BRN2 specific band shift. ${ }^{32}$ P-labeled UP (Table 1 and Fig. 4) was added to nuclear extracts $(5 \mu \mathrm{g})$ prepared from HEK293 cells transfected with scrambled (SC) or BRN2 (BRN2.1 or BRN2.2) siRNAs. Arrowheads indicate significant band shifts.

A)

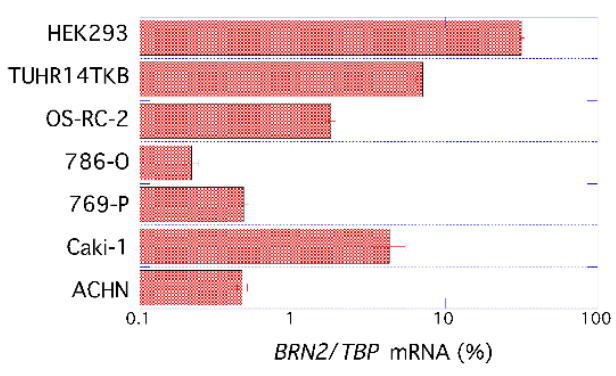

B)

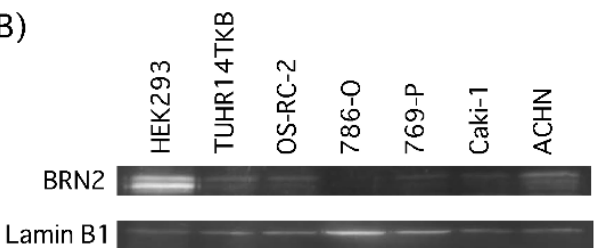

C)

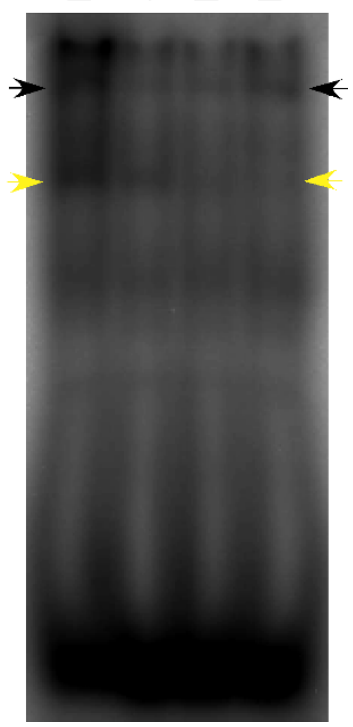


Caki-1) and that of a human embryonic kidney cell line (HEK293) (Figure 1A and 1B). These results are reminiscent of the report demonstrating that neither NFIC nor NFIX overexpression had any effect on endogenous $F A B P 7$ transcript levels although their overexpression decreased exogenous $F A B P 7$ promoter activity to $50 \%$ [18].

A possible explanation for this discrepancy is the nucleosomal organization of a chromosomal versus an episomal promoter. The basic unit of chromatin is the nucleosomal core particle, containing $147 \mathrm{bp}$ of DNA that wraps twice around an octamer of core histones. The core histones bear a highly dynamic $\mathrm{N}$-terminal amino acid tail approximately 20-35 residues long and rich in basic amino acids. These tails, which extend from the surface of the nucleosome, play an important role in folding of nucleosomal arrays into higher order chromatin structures that perform important functions in eukaryotic gene regulation [28]. Methylation of promoter $\mathrm{CpG}$ islands can play important roles in gene silencing [29]. However, this mechanism does not likely apply to human $F A B P 7$, since its promoter lacks a CpG island. We propose that an as-yet unidentified cis-acting negative regulatory element(s) residing either farther upstream or downstream from the region we analyzed in this study may explain the discrepancy between FABP7 mRNA levels and promoter activity.

Gene expression can be negatively regulated post-transcriptionally by microRNAs (miRNAs) [30], which play significant roles in cellular transformation and carcinogenesis by acting either as oncogenes or tumor suppressors [31]. A mechanism involving miRNAs may explain the discrepancy between FABP7 mRNA and protein expression levels.

Bisgrove et al. [17] reported that NFI is a key transcriptional activator of the $F A B P 7$ promoter in glioma cell lines. Our FABP7 promoter analysis reported here also showed that deletion of the NFI binding site downregulated promoter activity in the TUHR14TKB cell line (Figure $3 \mathrm{C}$ ), the only cell line positive for FABP7 protein expression. In glioma cell lines [17], NFI-DNA complexes were converted to a faster-migrating form by potato acid phosphatase treatment, indicating NFI activation by dephosphorylation [17]. Our gel shift analysis also revealed a similar association between the presence of a faster-migrating band (Figure $8 \mathrm{~A}$ ), FABP7 promoter

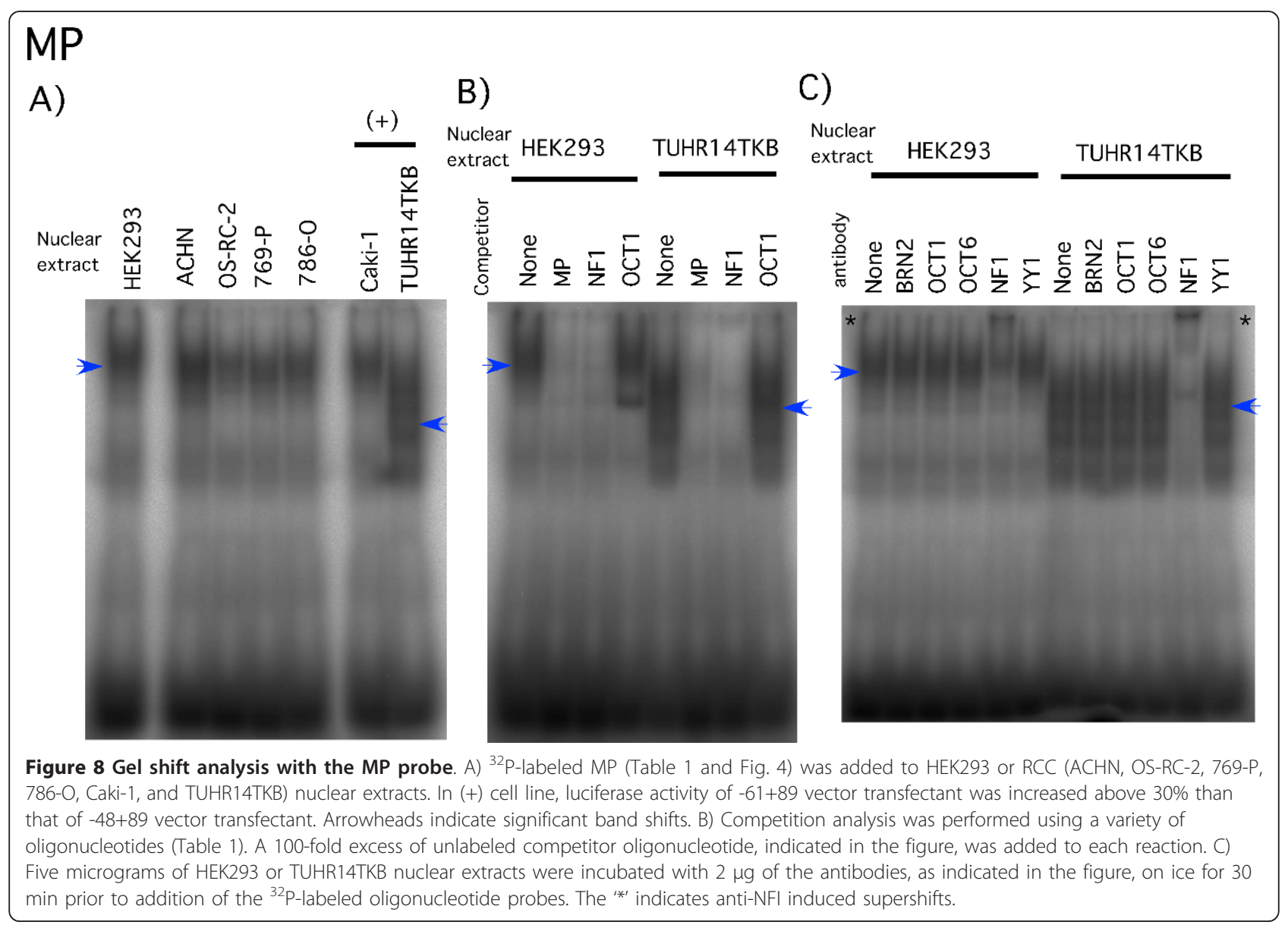


activation (Figure 3C), and FABP7 protein expression (Figure 1C).

NFIA and NFIC were, respectively, weaker and stronger in all six RCC cell lines than in HEK293 (Figure 7C). In a glioma cell line, NFIA and NFIC siRNAs inhibited and enhanced $F A B P 7$ promoter activity, respectively [18], thus indicating that $F A B P 7$ promoter activity in RCC cell lines may be weaker than that in the HEK293 cell line. This discrepancy might be attributed to a difference in FABP7 promoter regulation of NFIA and NFIC in RCC cell lines and glioma cell lines.

Deletion of the mouse Brn2 locus results in loss of specific neuronal lineages in the hypothalamus and consequent loss of the posterior pituitary gland [32,33]. A combination of three factors, Ascl1, Brn2 and Myt1l, suffice to rapidly and efficiently convert mouse embryonic and postnatal fibroblasts into functional neurons in vitro [34]. BRN2 may coordinate normal melanocytic differentiation, whereas BRN2 can be re-activated in melanoma and may play a role in melanoma cell proliferation and tumorigenesis [35]. BRN2 also plays an important role in keratinocyte differentiation and in the pathogenesis of lichen planus lesions [36]. Our results indicate that BRN2 represses the $F A B P 7$ promoter and suggests that regulation of $F A B P 7$ expression by BRN2 differs between RCCs and melanomas.

There is a contradiction between gel shift analysis by competing with OCT1 or OCT6 probe (Figure 5B) and gel shift analysis adding anti-OCT1 or anti-OCT6 antibody (Figure $5 \mathrm{C}$ ). One probability is that OCT1 and OCT6 probes bind to other transcription factor. However, it might be rare case for one transcription factor to bind to FABP7 promoter, OCT1 and OCT6 probes. Zwilling et al. reported that OCTl and OCT6 interact with high mobility group protein 2 [37]. This indicates that high mobility group protein 2 may form complex with OCT1 and OCT6. This putative complex may reflect band shift of upstream element competing with OCT1 and OCT6. Furthermore, OCT1 and OCT6 formed dimer on the consensus MORE [38]. Same complex may form on upstream element of FABP7 promoter. Forming OCT1-OCT6 complex might be disturbed in binding anti-OCT1 and anti-OCT6 antibodies to OCT1 and OCT6 respectively. Other possibility is that anti-OCT1 and anti-OCT6 antibodies cannot bind to OCT1 and OCT6 in our gel shift condition.

Our present finding that RCC cell lines differentially express $F A B P 7$ transcripts and protein, in contrast to the almost uniform overexpression of $F A B P 7$ transcripts by primary tumors, indicate the value of RCC cell lines for deciphering the mechanisms responsible for controlling FABP7 expression. Our future studies will focus on analyses of additional RCC cell lines to determine whether the low frequency of FABP7 expression is a consequence of selecting tumor cells for in vitro growth, and if so, will provide new insights into regulation of $F A B P 7$ expression. It will be important to determine whether primary tumors express FABP7 at the same high level as its transcript. If so, this would provide compelling evidence for FABP7's etiological role in RCC, and encourage future studies to evaluate it as a diagnostic marker and as a therapeutic target.

\section{Conclusions}

A high percentage of primary RCCs, but not RCCderived cell lines, express high FABP7 mRNA. The transcription factor BRN2 binds to the cis-acting regions in the $F A B P 7$ promoter identified in the present studies. BRN2 may repress the $F A B P 7$ promoter, because its expression inversely correlates with $F A B P 7$ promoter activity. NFI may also regulate FABP7 expression. Future studies will focus on analyzing these and other regulatory molecules in order to help design new therapies for treating RCC.

\section{Methods \\ Reagents}

Reagents and their sources were the following: GIBCO ${ }^{\circledR}$ RPMI Media 1640, oligo (dT) $12-18$, SuperScript ${ }^{\circledR}$ III Reverse Transcriptase and $\mathrm{pCR}^{\circledR} 2.1-\mathrm{TOPO}^{\circledR}$ vector, Invitrogen Corp. (Carlsbad, CA); SYBR ${ }^{\circledR}$ Green PCR Master Mix, Life Technologies (Carlsbad, CA); Oligopeptides and siRNAs, Hokkaido System Science (Sapporo, Hokkaido, Japan); Complete Protease Inhibitor Cocktail, FuGENE ${ }^{\circledR}$ HD Transfection Reagent, poly (dI$\mathrm{dC}$ ) and X-tremeGENE siRNA Transfection Reagent, Roche Diagnostics GmbH (Mannheim, Germany); BCA Protein Assay Reagent Kit and NE-PER Nuclear and Cytoplasmic Extraction Reagents, Thermo Fisher Scientific (Waltham, MA); Immobilon Western HRP Substrate, Millipore (Billerica, MA); HEPES, spermidine and dithiothreitol, Sigma-Aldrich (St. Louis, MO); PVDF membrane and Illustra MicroSpin G-25 columns, GE Healthcare UK Ltd. (Little Chalfont, Buckinghamshire HP7 9NA, England); pGL4.17 and pGL4.74 plasmids and Dual-Luciferase ${ }^{\mathbb{B}}$ Reporter (DLR ${ }^{\mathrm{TM}}$ ) Assay System, Promega (Madison, WI); restriction endonucleases and DNA Ligation Kit Ver.2.1, TAKARA BIO INC. (Otsu, Shiga, Japan); $\left[\gamma^{32} \mathrm{P}\right]$ dATP, Perkin Elmer Inc. (Waltham, MA); T4 Polynucleotide Kinase, Toyobo (Osaka, Japan); KCl, glycerol and NP-40, Wako (Osaka, Japan).

\section{Cell culture}

RCC cell lines (786-O, 769-P and ACHN) were purchased from the American Type Culture Collection (Manassas, VA). Caki-1, HEK293, OS-RC-2, and TUHR14TKB were provided by the RIKEN (Tsukuba, Ibaraki, Japan). All cell lines were grown in $\mathrm{GIBCO}^{\circledR}$ 
RPMI Media 1640 supplemented with 10\% (v/v) fetal bovine serum (Nichirei Biosciences Inc., Japan). Cells were cultured at $37^{\circ} \mathrm{C}$ in a humidified atmosphere containing $5 \%(\mathrm{v} / \mathrm{v}) \mathrm{CO}_{2}$.

\section{RT-PCR and Q-PCR analysis}

Cells were cultured in $100 \mathrm{~mm}$ dishes for two days. Total RNA was isolated from cultured cell lines using the RNeasy Mini Kit (QIAGEN, Hilden, Germany) according to the manufacturer's instructions. Either $5 \mu \mathrm{g}$ or $3 \mu \mathrm{g}$ RNA was reverse transcribed using the SuperScript ${ }^{\circledR}$ III Reverse Transcriptase primed by 500 ng of oligo $(\mathrm{dT})_{12-18}$ according to the manufacturer's recommendations. PCR amplification was performed using 1 $\mu \mathrm{L}$ of first-strand complementary DNA (cDNA) as template with the primers and number of cycles listed in Table 2. Amplified DNA was analyzed by electrophoresis through $2 \%$ or $3 \%(\mathrm{w} / \mathrm{v})$ agarose gels. Q-PCR analysis of FABP7 and BRN2 expression in RCC and HEK293 cell lines were done with the Applied Biosystems StepOnePlus $^{\mathrm{TM}}$ (Life Technologies). The final PCR reaction mix included $2 \mu \mathrm{L}$ of $5 \mu \mathrm{M}$ specific primer, $1 \mu \mathrm{L}$ firststrand cDNA and $10 \mu \mathrm{L}$ SYBR $^{\circledR}$ Green PCR Master Mix at a final volume of $20 \mu \mathrm{L}$. Specific plasmid controls for

Table 2 RT-PCR and Q-PCR primers

\begin{tabular}{|c|c|c|c|}
\hline cDNA & Sequence & $\begin{array}{l}\text { Annealing } \\
\text { temperature } \\
\left({ }^{\circ} \mathrm{C}\right)\end{array}$ & $\begin{array}{l}\text { Number } \\
\text { of cycles }\end{array}$ \\
\hline \multirow[t]{2}{*}{ FABP7 } & TGACCAACAGTCAGAACTTT & 54 & 40 \\
\hline & GCCATCCCATTTCTGTATGTG & & \\
\hline \multirow[t]{2}{*}{ TBP } & TTCGGAGAGTTCTGGGATTGTA & 58 & 40 \\
\hline & TGGACTGTTCTTCACTCTTGGC & & \\
\hline \multirow[t]{2}{*}{ BRN2 } & CGGCGGATCAAACTGGGATTT & 57 & 40 \\
\hline & TTGCGCTGCGATCTTGTCTAT & & \\
\hline \multirow[t]{2}{*}{ OCT1 } & GCATCCAACCACCAATTTGC & 57 & 30 \\
\hline & GAGGTGAGGGTGATGCTTG & & \\
\hline \multirow[t]{2}{*}{ OCT6 } & GCGGCGCATCAAGCTGGG & 63 & 38 \\
\hline & CGGTTGCAGAACCAGACGCG & & \\
\hline \multirow[t]{2}{*}{ NFIA } & CAGCCAAGTGACGCTGACA & 60 & 25 \\
\hline & CCTCATTGCTCCTGGACTCAT & & \\
\hline \multirow{2}{*}{$\begin{array}{l}N F I B \\
(1)\end{array}$} & CATAACCCAGGGAACTGGAG & 60 & 25 \\
\hline & CTCTITCGTGCCATGTTCGAC & & \\
\hline \multirow{2}{*}{$\begin{array}{l}N F I B \\
(2)\end{array}$} & CTCCCATCTGTCTCACTCAGG & 58 & 25 \\
\hline & CACGGGTGCTTCTTGCCAGTC & & \\
\hline \multirow[t]{2}{*}{ NFIC } & GGACAGGGATGGGCTCTG & 58 & 35 \\
\hline & CGTTCTTCTGAGGCCAGTGC & & \\
\hline \multirow[t]{2}{*}{ NFIX } & GTITTGTACTTCCGGGGTCTG & 58 & 35 \\
\hline & GGAAGGAGGGGAGGTGATG & & \\
\hline \multirow{2}{*}{$\begin{array}{l}\beta- \\
\text { actin }\end{array}$} & CAAACATGATCTGGGTCATCTTCTC & 60 & 25 \\
\hline & GCTCGTCGTCGACAACGGCTC & & \\
\hline
\end{tabular}

FABP7, BRN2 and TBP were synthesized as the direct insertion of PCR products into a $\mathrm{pCR}^{\circledR} 2.1$ - $\mathrm{TOPO}^{\circledR}$ vector, and standard curves for each marker were generated with seven serial dilutions of plasmid templates $(0.1 \mathrm{nM}$ to $0.1 \mathrm{fM})$. TBP was used as an internal control. The sense primer for $F A B P 7$ amplification, primers for $T B P$ amplification and primers for OCT6 amplification were reported by Teratani et al. [7], Jung et al. [39] and Faus et al. [40], respectively.

\section{Antibodies}

An anti-human FABP7 Antibody (AF3166) was purchased from R\&D Systems, Inc. Peroxidase-conjugated donkey anti-goat IgG (86285) was purchased from Jackson ImmunoResearch Laboratories, Inc. (West Grove, PA). A mouse monoclonal anti- $\alpha$-tubulin antibody (T6074) was purchased from Sigma-Aldrich (St. Louis, MO). Goat antimouse IgG-HRP (sc-2005), anti-Brn-2 (C-20: sc-6029 X), anti-Lamin B (M-20: sc-6217), anti-NF-1 (H-300: sc-5567 $\mathrm{X})$, anti-Oct-1 (C-21: sc-232 X), anti-Oct-6 (H-13: sc$11660 \mathrm{X})$ and anti-YY1 (H-414: sc-1703 X) were purchased from Santa Cruz Biotechnology, Inc. (Santa Cruz, CA).

\section{Western blot analysis}

Cells were cultured in 100-mm dishes for two days. Cytoplasmic and nuclear extracts were prepared using NE-PER Nuclear and Cytoplasmic Extraction Reagents. Protein concentrations were determined using the BCA Protein Assay Reagent. For FABP7 Western blot, cytoplasmic extracts $(20 \mu \mathrm{g})$ were electrophoresed through an $18 \%(\mathrm{w} / \mathrm{v})$ polyacrylamide-SDS gel. The proteins were electrophoretically transferred onto a PVDF membrane. Membrane was incubated with $1 \mathrm{mg} / \mathrm{mL}$ FABP7 antibody diluted 1:5000, and antibody-antigen complexes were visualized with peroxidase-conjugated antigoat IgG and Immobilon Western HRP Substrate. For BRN2 Western blot, nuclear extracts $(20 \mu \mathrm{g})$ were electrophoresed through a $10 \%(\mathrm{w} / \mathrm{v})$ polyacrylamide-SDS gel. Membrane transferring proteins was incubated with anti-Brn-2 (sc-6029 X) diluted 1:2000, and antibodyantigen complexes were visualized with peroxidase-conjugated anti-goat IgG and Immobilon Western HRP Substrate.

\section{Promoter constructs}

The pGL4-FABP7 promoter construct was generated by cloning a 2.1-kb PCR fragment of the human FABP7 promoter region into pGL4.17. PCR reactions, using the primers listed in Table 3, were performed to generate promoter region deletions, each ending at position +89 bp from the transcription start site. Amplified DNA fragments were digested with BglII and HindIII and, using DNA Ligation Kit Ver.2.1, ligated to BglII and HindIII-digested pGL4.17 [41]. 
Table 3 PCR primers used to prepare pGL4-FABP7 promoter constructs

\begin{tabular}{|c|c|}
\hline $\begin{array}{l}\text { Position, cloning site and } \\
\text { orientation }\end{array}$ & Sequence \\
\hline-1122 Bglll Sense & CTTCAGATCTGGTCAGCACTAGTAAG \\
\hline-468 Bglll Sense & CACTAAGATCTCTCCTITGTCTGCAAAG \\
\hline-351 Bg/ll Sense & ATCTTAGATCTTTTCCTTGCAGTCTGAG \\
\hline -192 Bg/ll Sense & GAACTAGATCTACTCCGCTAACCCAG \\
\hline -149 Bg/ll Sense & CAAAGAGATCTGGAGCCTCACTCGAGC \\
\hline-83 Bg/ll Sense & AGAGGAGATCTGGAGGGGTGTGTTTG \\
\hline-72 Bglll Sense & GAGAGATCTGTTTGCAATTTAAATCACTGG \\
\hline-61 Bglll Sense & TITGAGATCTAAATCACTGGATTITTGCCC \\
\hline-48 Bglll Sense & TCACAGATCTITTGCCCACCCTCTITCC \\
\hline-36 Bglll Sense & CCCAAGATCTTTCCAAATAAGAAGGCAG \\
\hline +89 Hindlll Antisense & ACAGAAAGCTTCCACCATCCTTGCCC \\
\hline
\end{tabular}

\section{Luciferase reporter assay}

Human RCC and HEK293 cell lines were grown at $37^{\circ} \mathrm{C}$ in GIBCO $^{\circledR}$ RPMI Media 1640 supplemented with $10 \%$ $(\mathrm{v} / \mathrm{v})$ fetal bovine serum in a humidified, $5 \% \mathrm{CO}_{2}$ atmosphere. Cells $\left(5 \times 10^{4}\right.$ or $\left.7 \times 10^{4}\right)$ were added to each well in 24 well plates and cultured for one day. Cells were transiently co-transfected with the pGL4-FABP7 promoter construct $(0.4 \mu \mathrm{g})$, pGL4.74 plasmid $(0.1 \mu \mathrm{g})$, and $2 \mu \mathrm{L}$ or $2.5 \mu \mathrm{L}$ FuGENE ${ }^{\circledR}$ HD Transfection Reagent. One day after transfection, luciferase activity was measured with a Dual-Luciferase ${ }^{\circledR}$ Reporter (DLR ${ }^{\mathrm{TM}}$ ) Assay System using a Lumicounter 700 (Microtech Niti-On, Japan).

\section{Gel mobility shift analysis}

Gel retardation assays were carried out using a slightly modified version of the method described by Bisgrove et al. [17]. Complementary oligonucleotides (Table 1) were annealed by heating at $95^{\circ} \mathrm{C}$ for $2 \mathrm{~min}$ and then cooling to room temperature. Probes were labeled with $\left[\gamma-{ }^{32} \mathrm{P}\right]$ dATP using T4 polynucleotide kinase and then purified using Illustra MicroSpin G-25 columns. Nuclear extracts were prepared using NE-PER Nuclear and Cytoplasmic Extraction Reagents. For each assay, $5 \mu \mathrm{g}$ of nuclear extract was used. Binding reactions were performed in $30 \mu \mathrm{l}$ binding buffer (20 mM HEPES $\mathrm{pH} 7.9,20 \mathrm{mM}$ $\mathrm{KCl}, 1 \mathrm{mM}$ spermidine, $10 \mathrm{mM}$ dithiothreitol, $10 \%(\mathrm{v} / \mathrm{v})$ glycerol, $0.1 \%(\mathrm{v} / \mathrm{v}) \mathrm{NP}-40$, and $2 \mu \mathrm{g}$ of poly $(\mathrm{dI}-\mathrm{dC})$ ). Two microliters of $5 \mu \mathrm{M}$ unlabeled competitor oligonucleotide or $1 \mu \mathrm{L}$ of $2 \mu \mathrm{g} / \mu \mathrm{L}$ antibody were added as appropriate. Following addition of the nuclear extract and incubation for $30 \mathrm{~min}$ on ice, $1 \mu \mathrm{L}$ of $100 \mathrm{nM}$ labeled probe was added and incubated for $20 \mathrm{~min}$ at room temperature. DNA binding reactions were electrophoresed through a $6 \%(\mathrm{w} / \mathrm{v})$ polyacrylamide gel in 0.5 $\times$ TBE to separate unbound probe from probe-protein complexes.

\section{siRNA transfection}

The BRN-2 siRNA sequences used were as follows: 5'GTGCAGACGCCCGTCCAG-3' (BRN2.1; [42]) and 5'CCGCAGCGTCTAACCACTA-3' BRN2.2; [43]). The scrambled control siRNA sequence was 3'-AAGTCCATGGTGACAGGAGAC-5' (SC; [43]). The siRNA was transfected into cells using X-tremeGENE siRNA Transfection Reagent according to the manufacturer's instructions. HEK293 cells were harvested 3 to 4 days after transfection.

\section{Additional material}

Additional file 1: Data of Q-PCR and luciferase reporter assay. Figure $1 \mathrm{~A}, \mathrm{~B}, 3 \mathrm{~A}, \mathrm{~B}, \mathrm{C}$ and $7 \mathrm{~A}$ - unprocessed data.

Additional file 2: FABP7 Western blot covering the full range Western blot was performed using cytoplasmic extracts from HEK293 and RCC (TUHR14TKB, OS-RC-2, 786-O, 769-P, Caki-1, and ACHN) cell lines.

Additional file 3: Gel shift analysis with the DP probe. A) ${ }^{32} \mathrm{P}$-labeled DP (Table 1 and Figure 4) was added to HEK293 or RCC (769-P, 786-O, ACHN, Caki-1, OS-RC-2, and TUHR14TKB) nuclear extracts. In (+) cell line, luciferase activity of $-48+89$ vector transfectant was increased above $30 \%$ than that of $-36+89$ vector transfectant. Arrowheads indicate significant band shifts. B) Competition analysis was performed using a variety of oligonucleotides (Table 1). A 100-fold excess of unlabeled competitor oligonucleotide, indicated in the figure, was added to each reaction. C) Five micrograms of HEK293 or 786-O nuclear extracts were incubated with $2 \mu \mathrm{g}$ of the antibodies, as indicated in the figure, on ice for $30 \mathrm{~min}$ prior to addition of the ${ }^{32} \mathrm{P}$-labeled oligonucleotide probes.

\section{List of abbreviations}

CDNA: complementary DNA; FABP7: fatty acid binding protein 7; NFI: nuclear factor I; miRNA: microRNA; mRNA: messenger RNA; Q-PCR: quantitative polymerase chain reaction (real-time polymerase chain reaction); PCR: polymerase chain reaction; RCC: renal cell carcinoma; RT-PCR: reverse transcriptase-polymerase chain reaction; siRNA: small interfering RNA; SDS: sodium dodecyl sulfate; TBP: TATA box binding protein; YY1: Yin Yang 1.

\section{Acknowledgements}

We thank Dr. Shigekazu Sasaki (Second Department of Internal Medicine, Hamamatsu University School of Medicine) for supporting our gel shift analysis, and Ms. H Misawa (Second Department of Internal Medicine), T Kageyama (Urology), M Miyazaki (Urology), H Fujita (Urology) and C Mochizuki (Urology) for their technical assistance. This work was supported by funding from a Grant-in-Aid for Scientific Research (C) 20591854 from The Ministry of Education, Culture, Sports, Science and Technology of Japan.

\section{Author details}

${ }^{1}$ Department of Urology, Hamamatsu University School of Medicine, Hamamatsu, Shizuoka, Japan. ${ }^{2}$ Division of Development of Advanced Treatment, Jichi Medical University, Shimotsuke-shi, Japan.

\section{Authors' contributions}

NT designed the study, performed the experiments, analyzed the data, and wrote the manuscript. TT1 participated in designing the study, analyzing the data and critically editing the manuscript. $T 2$, TS, SM and SO participated in critically editing the manuscript. All authors read and approved the final version of the manuscript.

\section{Competing interests}

The authors declare that they have no competing interests.

Received: 13 January 2011 Accepted: 19 July 2011 Published: 19 July 2011 


\section{References}

1. Weikert S, Ljungberg B: Contemporary epidemiology of renal cell carcinoma: perspectives of primary prevention. World J Urol 2010, 28:247-52.

2. Eichelberg C, Junker $\mathrm{K}$, Ljungberg B, Moch $\mathrm{H}$ : Diagnostic and prognostic molecular markers for renal cell carcinoma: a critical appraisal of the current state of research and clinical applicability. Eur Urol 2009, 55:851-863.

3. Haunerland $\mathrm{NH}$, Spener F: Fatty acid-binding proteins-insights from genetic manipulations. Prog Lipid Res 2004, 43:328-349.

4. Boord JB, Fazio S, Linton MF: Cytoplasmic fatty acid-binding proteins: emerging roles in metabolism and atherosclerosis. Curr Opin Lipidol 2002, 13:141-147.

5. Seliger B, Lichtenfels R, Atkins D, Bukur J, Halder T, Kersten M, Harder A, Ackermann A, Malenica B, Brenner W, Zobawa M, Lottspeich F: Identification of fatty acid binding proteins as markers associated with the initiation and/or progression of renal cell carcinoma. Proteomics 2005, 5:2631-2640

6. Domoto T, Miyama Y, Suzuki H, Teratani T, Arai K, Sugiyama T, Takayama T, Mugiya S, Ozono S, Nozawa R: Evaluation of S100A10, annexin II and BFABP expression as markers for renal cell carcinoma. Cancer Sci 2007 98:77-82.

7. Teratani T, Domoto T, Kuriki K, Kageyama T, Takayama T, Ishikawa A, Ozono S, Nozawa R: Detection of transcript for brain-type fatty Acidbinding protein in tumor and urine of patients with renal cell carcinoma. Urology 2007, 69:236-240.

8. Tölle A, Jung $M$, Lein $M$, Johannsen M, Miller $K$, Moch $H$, Jung $K$, Kristiansen G: Brain-type and liver-type fatty acid-binding proteins: new tumor markers for renal cancer? BMC Cancer 2009, 9:248.

9. Liang $Y$, Diehn $M$, Watson N, Bollen AW, Aldape KD, Nicholas MK Lamborn KR, Berger MS, Botstein D, Brown PO, Israel MA: Gene expression profiling reveals molecularly and clinically distinct subtypes of glioblastoma multiforme. Proc Natl Acad Sci USA 2005, 102:5814-5819.

10. Goto Y, Matsuzaki Y, Kurihara S, Shimizu A, Okada T, Yamamoto K Murata H, Takata M, Aburatani H, Hoon DS, Saida T, Kawakami Y: A new melanoma antigen fatty acid-binding protein 7 , involved in proliferation and invasion, is a potential target for immunotherapy and molecular target therapy. Cancer Res 2006, 66:4443-4449.

11. Goto $Y$, Koyanagi $K$, Narita N, Kawakami $Y$, Takata M, Uchiyama A, Nguyen L, Nguyen T, Ye X, Morton DL, Hoon DS: Aberrant fatty acid-binding protein-7 gene expression in cutaneous malignant melanoma. J Invest Dermatol 2010, 130:221-229.

12. Liang Y, Bollen AW, Aldape KD, Gupta N: Nuclear FABP7 immunoreactivity is preferentially expressed in infiltrative glioma and is associated with poor prognosis in EGFR-overexpressing glioblastoma. BMC Cancer 2006, 6:97.

13. Kaloshi G, Mokhtari K Carpentier C, Taillibert S, Lejeune J, Marie Y, Delattre JY, Godbout R, Sanson M: FABP7 expression in glioblastomas: relation to prognosis, invasion and EGFR status. J Neurooncol 2007, 84:245-248.

14. Slipicevic A, Jørgensen K, Skrede M, Rosnes AK, Trøen G, Davidson B, Flørenes VA: The fatty acid binding protein 7 (FABP7) is involved in proliferation and invasion of melanoma cells. BMC Cancer 2008, 8:276.

15. Zhang H, Rakha EA, Ball GR, Spiteri I, Aleskandarany M, Paish EC, Powe DG, Macmillan RD, Caldas C, Ellis 1O, Green AR: The proteins FABP7 and OATP2 are associated with the basal phenotype and patient outcome in human breast cancer. Breast Cancer Res Treat 2010, 121:41-51.

16. Shi YE, Ni J, Xiao G, Liu YE, Fuchs A, Yu G, Su J, Cosgrove JM, Xing L, Zhang M, Li J, Aggarwal BB, Meager A, Gentz R: Antitumor activity of the novel human breast cancer growth inhibitor, mammary-derived growth inhibitor-related gene, MRG. Cancer Res 1997, 57:3084-3091.

17. Bisgrove DA, Monckton EA, Packer M, Godbout R: Regulation of Brain Fatty Acid-binding Protein Expression by Differential Phosphorylation of Nuclear Factor I in Malignant Glioma Cell Lines. J Biol Chem 2000, 275:30668-30676.

18. Brun M, Coles JE, Monckton EA, Glubrecht DD, Bisgrove D, Godbout R: Nuclear factor I regulates brain fatty acid-binding protein and glial fibrillary acidic protein gene expression in malignant glioma cell lines. $\lrcorner$ Mol Biol 2009, 391:282-300.

19. Sánchez-Font MF, Bosch-Comas A, Gonzàlez-Duarte R, Marfany G: Overexpression of FABP7 in Down syndrome fetal brains is associated with PKNOX1 gene-dosage imbalance. Nucleic Acids Res 2003, 31:2769-2777.
20. NCBI FABP7 gene resource. [http://www.ncbi.nlm.nih.gov/gene/2173]

21. Tsunoda T, Takagi T: Estimating transcription factor bindability on DNA. Bioinformatics 1999, 15:622-630.

22. Transcription Element Search System. [http://www.cbil.upenn.edu/cgi-bin/ tess/tess].

23. Gronostajski RM: Roles of the NFI/CTF gene family in transcription and development. Gene 2000, 249:31-45.

24. Kochevar J: A renal cell carcinoma neoplastic antigen detectable by immunohistochemistry is defined by a murine monoclonal antibody. Cancer 1987, 60:2031-2036.

25. Fogh J, Trempe G: New human tumor cell lines. In Human Tumor Cells In Vitro. Edited by: Fogh J. New York: Plenum Press; 1975:115-141.

26. Williams RD, Elliott AY, Stein N, Fraley EE: In vitro cultivation of human renal cell cancer. II. Characterization of cell lines. In Vitro 1978, 14:779-786.

27. Tölle A, Krause H, Miller K, Jung K, Stephan C: Importance of brain-type fatty acid binding protein for cell-biological processes in human renal carcinoma cells. Oncol Rep 2011, 25:1307-1312.

28. Munshi A, Shafi G, Aliya N, Jyothy A: Histone modifications dictate specific biological readouts. J Genet Genomics 2009, 36:75-88.

29. Takai $D$, Jones PA: Comprehensive analysis of $C p G$ islands in human chromosomes 21 and 22. Proc Natl Acad Sci USA 2002, 99:3740-3745.

30. Bartel DP: MicroRNAs: target recognition and regulatory functions. Cell 2009, 136:215-233.

31. Wiemer EA: The role of microRNAs in cancer: no small matter. Eur $J$ Cancer 2007, 43:1529-1544.

32. Nakai S, Kawano H, Yudate T, Nishi M, Kuno J, Nagata A, Jishage K, Hamada H, Fujii H, Kawamura K, Shiba K, Noda T: The POU domain transcription factor Brn-2 is required for the determination of specific neuronal lineages in the hypothalamus of the mouse. Genes Dev 1995, 9:3109-3121.

33. Schonemann MD, Ryan AK, McEvilly RJ, O'Connell SM, Arias CA, Kalla KA Li P, Sawchenko PE, Rosenfeld MG: Development and survival of the endocrine hypothalamus and posterior pituitary gland requires the neuronal POU domain factor Brn-2. Genes Dev 1995, 9:3122-3135.

34. Vierbuchen T, Ostermeier A, Pang ZP, Kokubu Y, Südhof TC, Wernig M: Direct conversion of fibroblasts to functional neurons by defined factors. Nature 2010, 463:1035-1041.

35. Cook AL, Sturm RA: POU domain transcription factors: BRN2 as a regulator of melanocytic growth and tumourigenesis. Pigment Cell Melanoma Res 2008, 21:611-626.

36. Shi G, Sohn KC, Choi DK, Kim YJ, Kim SJ, Ou BS, Piao YJ, Lee YH, Yoon TJ, Lee $Y$, Seo YJ, Kim CD, Lee $\mathrm{H}$ : Brn2 is a transcription factor regulating keratinocyte differentiation with a possible role in the pathogenesis of lichen planus. PLoS One 2010, 5:e13216

37. Zwilling $\mathrm{S}$, König $H$, Wirth $\mathrm{T}$ : High mobility group protein 2 functionally interacts with the POU domains of octamer transcription factors. EMBO J 1995, 14:1198-1208.

38. Tomilin A, Reményi A, Lins $K$, Bak H, Leidel S, Vriend G, Wilmanns $M$, Schöler HR: Synergism with the coactivator OBF-1 (OCA-B, BOB-1) is mediated by a specific POU dimer configuration. Cell 2000, 103:853-864.

39. Jung M, Ramankulov A, Roigas J, Johannsen M, Ringsdorf M, Kristiansen G, Jung K: In search of suitable reference genes for gene expression studies of human renal cell carcinoma by real-time PCR. BMC Mol Biol 2007, 8:47.

40. Faus I, Hsu HJ, Fuchs E: Oct-6: a regulator of keratinocyte gene expression in stratified squamous epithelia. Mol Cell Biol 1994, 14:3263-3275.

41. Takaoka N, Fukuzawa M, Saito T, Sakaitani T, Ochiai H: Promoter analysis of the membrane protein gp64 gene of the cellular slime mold Polysphondylium pallidum. Biochim Biophys Acta 1999, 1447:226-230.

42. Goodall J, Carreira S, Denat L, Kobi D, Davidson I, Nuciforo P, Sturm RA, Larue L, Goding CR: Brn-2 represses microphthalmia-associated transcription factor expression and marks a distinct subpopulation of microphthalmia-associated transcription factor-negative melanoma cells. Cancer Res 2008, 68:7788-7794.

43. Wellbrock C, Rana S, Paterson H, Pickersgill H, Brummelkamp T, Marais R: Oncogenic BRAF regulates melanoma proliferation through the lineage specific factor MITF. PLoS One 2008, 3:e2734.

doi:10.1186/1471-2199-12-31

Cite this article as: Takaoka et al:: Analysis of the regulation of fatty acid binding protein 7 expression in human renal carcinoma cell lines. BMC Molecular Biology 2011 12:31. 